\title{
Ensino de Ciências
}

PRESENTE edição de Estudos Avançados obedece ao projeto, iniciado no número anterior, ${ }^{1}$ de aprofundar o conhecimento do 1 Ensino Médio e do Superior, quer das Humanidades, quer das Ciências Matemáticas, Físicas, Químicas e Biológicas. A complexidade das questões sobre o que e como ensinar resulta evidente quando se leem os textos aqui publicados. A riqueza dos dados básicos e das interpretações não comporta, evidentemente, resumos temáticos. O leitor escolherá, a seu critério, os artigos de seu interesse profissional e de sua curiosidade intelectual.

Além do conjunto principal publicam-se textos que completam, de algum modo, o dossiê de Humanidades (Bosi, 2018): assim, particular atenção é reservada à figura ímpar de Aníbal Quijano no seu diálogo com Mariátegui, e na colaboração que prestou ao Instituto de Estudos Avançados.

A editoria agradece aos professores Yvonne P. Mascarenhas, Umberto G. Cordan, Hernan Chaimovich, Marcos S. Buckeridge e Flavio Ulhoa Coelho a prestante ajuda na constituição dos minidossiês sobre ensino de Física, de Geologia, de Química, de Biologia e das Matemáticas.

Este número é dedicado a Ernest Hamburger (2007), ${ }^{2}$ infatigável difusor da história e das ciências dentro e fora da Universidade de São Paulo.

\section{Alfredo Bosi ${ }^{\text {I }}$}

${ }^{\text {I }}$ Faculdade de Filosofia, Letras e Ciências Humanas, Universidade de São Paulo, São Paulo, São Paulo, Brasil.

\section{Notas}

l A $93^{\text {a }}$ edição da revista inaugurou a série focada nos ensinos fundamental e médio. O dossiê trouxe um conjunto de artigos sobre o Ensino de Humanidades, área do conhecimento escolhida para abrir a sequência. Além de ponderações sobre a conjuntura atual da educação brasileira, os textos apresentam reflexões sobre o ensino de filosofia, história, geografia, música, literatura e religião. A versão online da publicação está disponível na íntegra no SciELO.

2 Ernst Wolfgang Hamburger (1933-2018). Físico nuclear foi um dos criadores do Laboratório de Demonstrações do Instituto de Física da USP e diretor da Estação Ciência. 


\section{Referências}

BOSI, A. Ensino de Humanidades. Estudos Avançados, v.32, n.93, p.3, mai-ago. 2018. Disponível em: <http://www.scielo.br/scielo.php?script=sci_arttext\&pid=S0103-40142018000300003>. Acesso em: 15 out. 2018.

HAMBURGER, E.W. Apontamentos sobre o ensino de Ciências nas séries escolares inciais. Estudos Avançados, v.21, n.60, p.93-104, mai-ago. 2007.

Disponível em: <http://www.scielo.br/scielo.php?script=sci_arttext\&pid=S0103-40142007000200007\&ln $\mathrm{g}=\mathrm{en} \& \mathrm{nrm}=\mathrm{iso} \& \mathrm{tlng}=\mathrm{pt}>$. Acesso em: 15 out. 2018. 